\title{
A!
}

This is an electronic reprint of the original article.

This reprint may differ from the original in pagination and typographic detail.

Kallio-Tavin, Mira

\section{Disability Studies as a site of knowledge in art education}

Published in:

International Journal of Education through Art

Published: 01/03/2020

Document Version

Peer reviewed version

Please cite the original version:

Kallio-Tavin, M. (2020). Disability Studies as a site of knowledge in art education. International Journal of Education through Art, 16(1), 3-11.

This material is protected by copyright and other intellectual property rights, and duplication or sale of all or part of any of the repository collections is not permitted, except that material may be duplicated by you for your research use or educational purposes in electronic or print form. You must obtain permission for any other use. Electronic or print copies may not be offered, whether for sale or otherwise to anyone who is not an authorised user. 


\title{
EDITORIAL
}

\author{
MIRA KALLIO-TAVIN \\ Aalto University, Finland
}

\section{Disability studies as a site of knowledge in art education}

\begin{abstract}
Disability studies has become an important site of knowledge in the field of art education, among many other fields. As a part of the social justice approach in art education, disability studies enlighten people's experiences and allow room for previously unheard and silenced voices. Many of these voices have not been included in educational discourses before. Until recently, students' non-normative experiences have been called 'special', as if they did not concern everybody, but only people who were labelled as non-abled and who did not fully own agency in their own lives, or did not fully belong to society with the same rights as the rest of the population. This condition of a normative society, called ableism, is similar to other forms of oppression, such as sexism, classism and racism. Ableism is the production of a normative thinking that assumes bodies to be able-bodied and that marginalizes people based on their disabilities. Ableist production sustains and recreates cultural barriers based on difference and inequality and 'others' people who are not in line with normative physical, mental or behavioural ideals. Although disability was historically excluded from social justice theory for a long time (Derby 2011), disability studies can be seen as an area of social justice, similar to other social justice areas that have been of great interest to art educators. As Marta Madrid-Manrique points out in her article in this issue, disability studies also serve as a strong advocate for disability rights.

As is evident through the articles in this issue, the disability studies approach does not provide a practical toolkit for educators, but rather offers the possibility of a deep understanding of the lives of disabled people and
\end{abstract}


a world-view beyond ableist and normative thinking. In particular, disability studies perspectives have emphasized how the different areas of cultural identification are overlapping and simultaneous, intersecting, sometimes requiring negotiation (Mingus 2011). Following the transformative power of social justice art education, through promoting critical awareness within diverse types of cultural and political oppressions (Dewhurst 2014), disability studies has a great potential to inform arts learning from non-ableist perspectives (Derby 2016; Penketh 2014). On the other hand, arts learning offers multiple ways to explore disability cultures and their representations and scrutinize them in creative and critical ways, ultimately imagining alternative non-ableist futures, as demonstrated in many articles in this issue. Some articles explore the possibilities of arts-based research methods to offer access to disability experiences and cultures. Arts-based research methods can become powerful sites of knowledge within disability experiences, as we can read, for example, in Alexandra Allen's and Madrid-Manrique's articles in this issue.

Art educators might have noticed that in addition to this issue, there are multiple other efforts taking place within disability studies, art and education (DSAE). A special issue of the IMAG Journal on Disability, Art, Justice and Intersectionality was published last year (Wexler and Kallio-Tavin 2019). The first International Conference on Disability Studies, Arts, and Education (DSAE) was held on 28-29 September 2017 at Aalto University, Helsinki. The second International DSAE conference was organized at the Moore College of Art and Design, Philadelphia, on 3-5 October 2019. After the first conference, a special issue on disability studies, arts and education was published in the Research in Art Education journal (previously Synnyt / Origins, the Finnish Studies in Art Education) (Wexler and Derby 2018). The special issue based on the second conference will be published in the same journal in 2020. In 2017, DSAE was also established as a new interest group in the NAEA, the National Art Education Association for North America. Many of these activities are gathered under the DSAE web pages (https://dsae.online), created to support the network for the international research community in disability studies within arts and education, aiming to bring a critical disability studies perspective to the arts, culture, education and society at large.

\section{DISABILITY AS CULTURAL IDENTITY}

Historically, disability has been difficult to relate to, even though it has always been part of human societies. Simo Vehmas (2012) sums up how during Antiquity and the Middle Ages, disability was believed to be a consequence of a transgression, a result of moral wrongdoing. People with disabilities were either isolated from society or killed. Throughout modern times, disability has been connected, and is often still connected, to bad luck (an accident), bad habits (wrong diet and intoxicants) or bad genes (Vehmas 2012). Normalcy has become a measurement of humanity, a standard that we learn early in life, and abnormalcy (disability) an undesirable deviation from the norm. Similar to discrimination against people based on ethnicity or gender, historically people with disabilities have been the objects of abuse and control. As Connor and Gabel write, 'the consensus has traditionally been, " $[\mathrm{t}]$ hey do not belong with us"' (2013: 101).

In critical disability studies, disability is recognized as a cultural identity comparable with other minority identities, rather than a limiting factor, a problem or a void in individuals' lives. The disabled bodymind provides insight into 
the fact that all embodied individuals and groups of people are socially, rather than biologically, constructed. Social attitudes, the material conditions of society and institutional determination build dominant ideas and perceptions of the body more strongly than the biological representation of the body's reality. Disability is seen as something that is formulated at the intersection of society and its discourses that create and maintain disability through values, conventions and significances (Osteen 2008; Siebers 2006; Wilson and LewieckiWilson 2004). To sum up, in critical disability studies, disability is not primarily seen as a biological condition, but rather as a result of barriers in social structures and practices (Oliver 1990).

Understanding disability as a socially constructed phenomenon is often referred to as the social model or sociopolitical orientation to disability (Blandy 1991; Eisenhauer 2007). This model was coined to respond to and reconstruct the so-called medical model, or clinical, deficit or tragedy model (in the literature, all of these are used and indicate the same model), which sees disability mainly as a personal tragedy and potentially treatable via various treatments and therapies, defined by external medical experts (Swain and French 2000). The medical model understands disability as an undesirable condition and targets disabled people's bodies as sites of intervention. Research on disability in the medical model has mostly concentrated on the clinical or practical fields. The medical model presents disability as a problem or as an impairment to be cured, or at least mitigated. The medical concept of disability emerged at a specific time in history and should therefore be reviewed with a critical eye in the contemporary era, where the insights of feminism, postmodernism, postcolonial theory and social studies make it possible to analyse disability as a sociopolitical and cultural construction. Unfortunately, that is not what always happens.

The most problematic dimension of the medical model is how it patronizes individuals' own experiences, disparaging disability's significance as a cultural identity and centralizing the expertise of a non-disabled person, who often does not have experience of the lives of the disabled, but who nevertheless is given the key role in decision-making. Too often, decisions made for people with disabilities are based on ableist values and normative perspectives. In short, in the medical model, the role of the external medical expert is seen as overtly powerful over individuals' lives.

Acknowledging all bodies as sociopolitically constructed has helped people opposing the medical model discourses to understand disability as a socially constructed phenomenon. As Tom Shakespeare (1992) has stated, the real cause of disability is discrimination and prejudice, not an impairment. There is a common assumption in society, sustained by non-disabled people, about abled normalcy, which includes the idealized able bodymind. The idealized able bodymind is not, however, often desired per se by people with disabilities, who might instead consider disability as a natural part of their lives. For many, it would be impossible to think about their own life without disability, as it would be difficult, if not impossible to think of one's own life altogether as a different person. It is indeed societal expectations about 'normalcy' that bring the limitations, as a person with disabilities needs to undertake constant 'adjusting and accepting' to get by in the ableist designed and ableist thought society (Swain and French 2000: 573).

Recognizing disability as a valuable cultural identity to be proud of, similar to other minority culture identities, such as race, class and gender, has brought disability into a new discussion within the past two decades. The so-called 
affirmative model values disabled individuals' own lifestyles as culture and as cultural identity (Swain and French 2000). The affirmative model promotes varied and diverse bodymind experiences about being and living in the world, and brings rich understanding and knowledge based on individuals' contributions of diverse bodymind experiences.

Disability culture refers to a diverse group of people with diverse physical or mental conditions, who often experience cultural discrimination, stigmatization, segregation and medicalization (Eisenhauer 2007). Talking about disability culture can hence refer to multiple different understandings and experiences of what disability as a cultural identity might mean. Some disability culture groups might be represented through specific disability cultures, such as mad culture, crip culture, intellectual disability culture and D/deaf culture. Jones and Collins discuss the diversity of the disability cultures in their article in this issue. These diverse groups and individuals also have different identities and different understandings of their own (dis)abilities. Perhaps the most important aspect when discussing disability cultures is to listen to how the representatives discuss and represent their cultural identity. The diversity of disability as lifestyle is best reflected when all individuals have the opportunity to represent them/ourselves, and individuals' experiences are respected and acknowledged. An important method of representing disability culture is writing from own lived experiences. In this issue, Allen and Roman et al. write their articles from this powerful self-voiced perspective.

Disability can, through many people's lives, be seen as a positive, indeed enabling, condition for powerful lives. Following the line of disability studies and looking at society through an anti-ableist perspective allows space for new determinations and alternative societal futures. Using the concept of disability to explore everyday practices, functionalities and temporalities helps us to see our societies differently and aim our practices towards transformative education.

\section{RETHINKING THE ART CURRICULUM}

As roughly 15 per cent of the population (WHO 2019) identify themselves as belonging to the disability culture, it is likely that most people experience disability somehow and in some way in their lives. It is actually likely that every person is touched by non-normative bodymind experiences during their lives somehow. Hence, including disability cultures in the art curriculum seems pivotal. In fact, DSAE has been an emerging area of educational practices and research since the early 1990s (Blandy 1991, 1994). Until recently, it has been a focus area for a quite small group of researchers (Derby 2016; Eisenhauer 2008; Kallio-Tavin 2013; Keifer-Boyd et al. 2018; Penketh 2014; Wexler 2016). These art educators have found it important to seek alternative approaches to the special education discourse, and by reaching out to the disability studies in education (DSE), find new methods for DSAE. This issue takes part in developing this conversation and expanding the growing area of research.

Many of the articles in this issue have been written from a teacher's perspective and in an educational context. It is indeed important to ponder how educational contexts can be contemplated beyond special education in non-normative and anti-ableist perspectives. For a long time, 'students with disabilities have been spoken for, to and about by art educators' (Wexler 2016: 32, original emphasis), and their own voices have not been heard. In this 
issue, articles from Claire Penketh, Marta Madrid-Manrique, Kelly M. Gross, and Jones and Collins particularly take part in this conversation.

In terms of making space for first-person voices and stopping speaking for others, Connor and Gabel have emphasized two methods when working with DSE approaches: the first relies on research: 'expanding questions, pluralizing methods' (Connor and Gabel 2013: 106) and the second on practice: 'promoting access, supporting flexibility' (Connor and Gabel 2013: 107). Expanding questions and pluralizing methods include unlearning stereotypes through critiquing the status quo. This strategy has been the leading approach in the articles in this issue. Promoting access and supporting flexibility can be taken up in everyday practices in schools, focusing on the overall structures and teachers' and students' conversations on normalcy in relation to disability. In these conversations, the school structures, practices and curriculum can be critically reviewed regarding how disability cultures are present and shaping the structures, or perhaps missing or misrepresented (Connor and Gabel 2013). One practice is to support inclusive education, meaning integrating all students into general classrooms. Inclusive classrooms can be seen as places that 'widen the circle of acceptance and understanding and [demonstrating] that it is within the power of our imaginations to reinvent the world in a way that we desire, using lessons that have been learned so far' (Connor and Gabel 2013: 108).

Taking first-person voices seriously and allowing room in schools for students' experiences of non-normative bodyminds does not mean that nondisabled teachers cannot be disability advocates. In fact, this is a common misunderstanding and sometimes leads teachers to feel that it is better not to include disability in their curriculum at all, as they do not have the knowledge and experience or the right to speak to it. However, one can be a disability advocate and activist, as long as first-person voices as experts are included and invited to join the conversation, and as long as learning from narratives voiced by first-person experts is maintained as the primary source of knowledge. A non-disabled teacher can never be an expert, and that humble pedagogical approach needs to be valued every day.

Robert McRuer has developed crip theory and 'cripistemologies' to challenge the natural order of 'compulsory able-bodiedness' (2006: 1). The term 'cripistemology' emphasizes the importance of crip theory as a source of societal knowledge that can help to determine what we might become (McRuer and Johnson 2014). As Clair Penketh writes in her article in this issue, crip theory insists on resisting neat resolutions. Crip theory aligns with queer politics and questions normalized practices in society, including education, within ability and in heteronormativity. By resisting seeking quick answers and easy solutions, practising crip theory in the curriculum can be seen to be productive through its power of questioning existing educational and societal systems, notions and values. Although the idea of resisting solutions might be somewhat distant from everyday classroom education, through continuous questioning, this resistance attitude might become a powerful tool for educators who reach beyond ableist and normative teaching.

\section{ARTICLES IN THIS ISSUE}

In her opening article, Penketh describes how 'cripping' the art education curriculum means questioning naturalized assumptions, reinforcing classroom practices through critical explorations and challenging the idea of a division 
between able students and disabled students. Penketh introduces anti-ableist theory as a vital pedagogy in art education, through a research project with art teachers, who were invited to contemplate their notions regarding ability, and 'crip' those notions from an anti-ableist position. The article introduces an interesting effort of taking theory to practice. The outcome of the research project indicated great potential for the wider application of crip theory in art education.

Chelsea Jones and Kim Collins call to 'people' disability culture, that is, as they write, 'to connect the theoretical texts in the field of disability studies with local people whose day-to-day work resists ableism and contributes to disability culture'. By drawing on intersectionality, crip ideology and Disability Justice, and by discussing their research project on producing student-directed disability activist films, they share powerful narrations of lived experiences of affirmative models of disability. In their article they share the three-year extensive filming journey, which eventually produced five accessible documentary films. The discussed short films address important themes in disability culture, such as institutional survivorship, accessible city building and disability and mad pride.

Marta Madrid-Manrique discusses the complexity of encountering the unwillingness of young people and children with disability to participate in workshop activities. She narrates the complexity of (non)participation through the form of comic art and places her narration in an animated film workshop. She discusses why and how empowerment might - or might not - take place in these situations, and how they are connected to ethical responsibility. Madrid-Manrique suggests that (non)participation is an often-overlooked phenomenon within participatory research methods, and finds arts-based educational research to be a powerful method for taking responsibility for (non)participation and providing a sense of integrity, sincerity and authenticity when working as an educator with a commitment. Taking the comic art form, the article suggests the comic as a site of knowledge as a relational creative process.

In their article, Leslie G. Roman, rena del pieve gobbi, Jonas-Sébastien Beaudry and Persimmon Blackbridge share important research on selfvoiced disability experiences. Their exploration takes place in an artists' and scholars' retreat, rupturing and transforming conventional artistic practices. They take two concepts as a starting point: Hoffstadter's recursion and Irwin's a/r/tography, and ask how artistic practices and genres might reflexively transform. Following the time span and rhythm of the retreat, the article engages with essential political, historical, colonial and artistic questions. With their polyvocal research article, which includes strong individual narrations, and through their multifaceted art production, they seek a larger sociocultural transformation of disability politics.

Alice Wexler discusses the art production of a neuro-diverse artist, George Widener. Through exploring Widener's art production, Wexler suggests that readers re-imagine art in society and in schools. By giving a voice for Widener to speak for his own art production, unlike what has historically often been offered to autistic or Outsider artists, Wexler offers an insight into Widener's rich art production. The contentious category of Outsider Art is discussed as a deeply political category, not as an aesthetic category, as it is often considered. She explores how artists considered as Outsider artists contribute to a sharper awareness of our own identities and circumscribed realities. 
Alexandra Allen's article turns us back towards self-voiced experience of disability. In her arts-based research she explores moments of critical disability awareness in a normative society. Through critical autobiographical reflection, she increases understanding of what it is like to embody invisible disabilities, and through critical disability studies discourse she discusses how people with disabilities have become disenfranchised in a society that considers ablebodiedness as a norm. In her written narratives, she demonstrates how her own internalization of ableist ideas influences her own understanding of her identity within ableist societal expectations. She defines invisible disabilities as a borderland of disability experience and abledbodiedness, where she defines herself as engaging in acts of performative ablebodiedness.

Jennifer Watt continues with the perspectives of invisible disabilities, and discusses how they often go unacknowledged, unidentified or unsupported. Watt's article offers parents' perspectives on dyslexia experiences through artsbased group activities and interviews. Through image-making, the parents involved in the study explore both the challenges and the empowering aspects of their experiences when parenting a child with a learning disability. The research approach supports affirmative acknowledgement and strength-based perspectives by making visible the complex life experiences of individuals and their family members with dyslexia.

In her concluding article, Kelly M. Gross reports a study on social interaction skills with students with emotional disabilities (ED) in an inclusive art room. She shares findings that indicate a strong link between participation in visual art and the development of social relationships. This case study introduces observations of students' social interactions in an inclusive art classroom with a progressive postmodern visual culture curriculum, and semi-structured interviews with their teachers. It explores students' engagement in learning, their areas of interest, their relationship to their teacher, their interaction with their peers and how the pedagogical environments supported their interaction and learning. This study emphasizes the importance of students' peer learning and recommends that teachers integrate social interactions into the daily curriculum and include more opportunities for practising social skills in reallife situations, in a less structured environment.

This issue's strong submissions show in a powerful way how disability studies has become a site of knowledge in the field of art education. The articles also provide excellent examples of how art can serve as a realm of research for disability cultures, in addition to serving as a strong method, as in arts-based research. The articles in this issue provide a critique of ablebodiedness as a societal norm, and offer a sharper awareness through insights into disabled artists' production. More than anything else, the articles share lived disability life experiences, and learning experiences, in unique and valuable ways. These ways include self-voiced narrations and critical teachers' and parents' perspectives, and they all resist ableist societal and educational practices and neat resolutions.

\section{REFERENCES}

Blandy, Doug (1991), 'Conceptions of disability: Toward a sociopolitical orientation to disability for art education', Studies in Art Education, 32:3, pp. 131-44.

(1994), 'Assuming responsibility: Disability rights and the preparation of art educators', Studies in Art Education, 35:3, pp. 179-87. 
Connor, David and Gabel, Susan (2013), "“Cripping" the curriculum through academic activism: Working toward increasing global exchange to reframe (dis)ability and education', Equity \& Excellence in Education, 46:1, pp. 100-18.

Derby, John (2011), 'Disability studies and art education', Studies in Art Education, 52:2, pp. 94-111.

— (2016), 'Confronting ableism: Disability studies pedagogy in preservice art education', Studies in Art Education, 57:2, pp. 102-19.

Dewhurst, Marit (2014), Social Justice Art: A Framework for Activist Art Pedagogy, Cambridge, MA: Harvard Education Press.

Eisenhauer, Jennifer (2007), 'Just looking and staring back: Challenging ableism through disability performance art', Studies in Art Education, 49:1, pp. 7-22.

- (2008), 'A visual culture of stigma: Critically examining representations of mental illness', Art Education, 61:5, pp. 13-18.

Kallio-Tavin, Mira (2013), Encountering Self, Other and the Third: Researching the Crossroads of Art Pedagogy, Levinasian Ethics and Disability Studies, Helsinki: Aalto University Press.

Keifer-Boyd, Karen, Bastos, Flavia, (Eisenhauer) Richardson, Jennifer and Wexler, Alice (2018), 'Disability justice: Rethinking "inclusion" in arts education research', Studies in Art Education, 59:3, pp. 267-71.

McRuer, Robert (2006), Crip Theory: Cultural Signs of Queerness and Disability, New York: New York University Press.

McRuer, Robert and Johnson, Merri Lisa (2014), 'Proliferating cripistemologies a virtual roundtable', Journal of Literary and Cultural Disability Studies, 8:2, pp. 149-69.

Mingus, Mia (2011), 'Changing the framework: Disability Justice: How our communities can move beyond access to wholeness', Leaving Evidence, 11 February, https://leavingevidence.wordpress.com/2011/02/12/. Accessed 26 August 2019.

Oliver, Michael (1990), The Politics of Disablement, London: MacMillan.

Osteen, Mark (2008), Autism and Representation, New York: Routledge.

Penketh, Claire (2014), 'Putting disability studies to work in art education', International Journal of Arts \& Design Education, 33:3, pp. 291-300.

Shakespeare, Tom (1992), 'A response to Liz Crow', Coalition, September, pp. 40-42.

Siebers, Tobin (2006), 'Disability in theory. From social constructionism to the new realism of the body', in L. J. Davis (ed.), The Disability Studies Reader, New York: Routledge, pp. 173-83.

Swain, John and French, Sally (2000), 'Towards an affirmation model of disability', Disability \& Society, 15:4, pp. 569-82.

Vehmas, Simo (2012), 'Vammaisuus kulttuurisena konstruktiona', in M.-L. Honkasalo and H. Salmi (eds), Terveyttä kulttuurin ehdoilla: Näkökulmia kulttuuriseen terveystutkimukseen, Turku: Turku University Press, pp. 269-89.

Wexler, Alice (2016), 'Re-imagining inclusion/exclusion: Unpacking assumptions and contradictions in arts and special education from a critical disability studies perspective', The Journal of Social Theory in Art Education, 36, pp. 32-42.

Wexler, Alice and Derby, John (eds) (2018), Synnyt/Origins: Finnish Studies in Art Education, Special Issue: 'Disability Studies, Arts, and Education', 2, pp. 1-125, https://wiki.aalto.fi/pages/viewpage.action?pageId=145101810. Accessed 9 September 2019. 
Wexler, Alice and Kallio-Tavin, Mira (eds) (2019), 'Disability, art, justice and intersectionality', IMAG Journal, 8.

Wilson, James C. and Lewiecki-Wilson, Cynthia (2004), 'Disability, rhetoric, and the body', in J.C. Wilson and C. Lewiecki-Wilson (eds), Embodied Rhetorics: Disability in Language and Culture, Carbondale, IL: Southern Illinois University Press, pp. 1-24.

WHO (2019), 'Report on disability', World Health Organization, https://www. who.int/disabilities/world_report/2011/report/en/. Accessed 4 April 2019.

\section{CONTRIBUTOR DETAILS}

Associate professor Mira Kallio-Tavin (Doctor of Arts), is the head of research in the Department of Art in Aalto University, Finland. She focuses her research on critical artistic and arts-based practices and research in questions of diversity, disability studies, social justice and critical animal studies. She is the chair of disability studies in art education (DSAE) interest group in the NAEA (National Art Education Association) in the United States, world councillor of InSEA (International Society for Education Through Art), and the founder of the International DSAE conference.

Contact: Aalto University, School of Arts, Design and Architecture, Department of Art, Otaniementie 14, 02150 Espoo, Finland.

E-mail: mira.kallio-tavin@aalto.fi

(-) https://orcid.org/0000-0002-6131-4033

Mira Kallio-Tavin has asserted her right under the Copyright, Designs and Patents Act, 1988, to be identified as the author of this work in the format that was submitted to Intellect Ltd. 